\title{
Coatings: A Review
}

\author{
Divya $^{1}$ and Rutash Mittal ${ }^{2}$ \\ ${ }^{1}$ Department of Mechanical Engineering GZSCCET, Bathinda, Punjab India \\ ${ }^{2}$ Department of Mechanical Engineering, MIMIT, Malout, Punjab India \\ E-Mail: divyagaur51196@gmail.com
}

\begin{abstract}
To protect and safeguard a material from degradation, another material having better properties is applied on the base metal. The application of a coated material can propel the increase in life span, wear resistance or oxidation resistance of a material. Thermal spray coatings play an important role to protect the material from hot corrosion, erosion and wear. As it protects the material from this hazardous environment, it is helpful to increase service life of the material in any surrounding environment. This review paper presents the results of previous work done by different authors in the field of coating.
\end{abstract}

Keywords: Hot Corrosion, Thermal Spraying

\section{INTRODUCTION}

Coatings provide protection to any material from wear, hot corrosion and erosion in any surrounding environment. Coating material can be in any form like powder form, wire form, molten form and ceramic rod. Porosity of coating depends upon the sprayed material and condition of the spray. Mainly, there are three kinds of coating techniques i.e. thermal spraying, physical vapour deposition (PVD), chemical vapour deposition(CVD) But thermal spray coating techniques are widely used technique to coat any material. Some examples of thermal spray techniques are detonation gun technique, HVOF technique, plasma spray etc. Coatings also play precious role in medicine field as well as in industrial field. Coating tests are performed in both molten salt environment and in air environment. Some application of coatings are in automotive systems, boiler components, power generation equipments, aircraft engines, orthopedics and dental, ships, land-based and marine turbines [1].

\section{STUDIES RELATED TO COATINGS}

Fauchais et al. [2] Studied the thermal sprayed coatings used against corrosion and corrosion wear. He concluded that there were some reasons to use thick thermal sprayed coatings in industries. The reasons are as follows:1) It provided some beneficial properties to the substrate. 2) With low or no heat input, it could be applied to substrate. 3)Thermal sprayed coatings could be recoated the damaged or worn coatings without any changes in dimensions and properties. 4) Some of thermal processes could be used to spray big parts easily. He also concluded some negative points of this coating like. 1) It was impossible to coat deep cavities and small parts by this coating process. 2) It had pores and cracks which resulted degradation. Hence post- treatments like annealing, sealing, laser glazing etc. must to remove pores. These post-treatments increased the cost of coating.

Kaur et al. [3] investigated the high temp. Corrosion of HVOF sprayed $\mathrm{Cr}_{3} \mathrm{C}_{2}-\mathrm{NiCr}$ coating on SAE $347 \mathrm{H}$ boiler steel at $700^{\circ} \mathrm{C}$. $\mathrm{Na}_{2} \mathrm{SO}_{4} 82 \mathrm{Fe}_{2}\left(\mathrm{SO}_{4}\right)_{3}$ solution was used as molten salt solution. She concluded that coating on 347 boiler steel by HVOF achieved great results and sprayed coating consisted irregular shaped splats which were interconnected. Corrosion loss for $347 \mathrm{H}$ steel in molten salt solution was high than corrosion loss in air and bare $347 \mathrm{H}$ steel in both environment suffered accelerated oxidation. Coated $347 \mathrm{H}$ steel showed better corrosion resistance in both environment than bare steel.

Kaur et al. [4] examined the surface engineering of D-gun sprayed $\mathrm{Cr}_{3} \mathrm{C}_{2}-\mathrm{NiCr}$ coating under high temp. Oxidation and Oxidation erosion environment. She concluded that coating on T22 boiler steel by D-gun achieved great results and coating had spongy structure. Higher weight loss occurred by bare specimen than coated at $700+10^{\circ} \mathrm{C} / 700-$ $10^{\circ} \mathrm{C}$. Coated $\mathrm{T} 22$ steel resulted good oxidation erosion resistance than uncoated $\mathrm{T} 22$.

Arrieta et al. [5] determined the corrosion behavior of $\mathrm{NiCr}$ based coatings in simulated human body fluid environment. $\mathrm{He}$ concluded that $\mathrm{NiCr}$ coatings were high corrosion resistant or had low corrosion rate and pitting corrosion resistance .But by adding $\mathrm{Cr}_{3} \mathrm{C}_{2}$ in $\mathrm{NiCr}$, corrosion resistance had increased more. $\mathrm{NiCrAl}$ coating had highest pitting potential value But $\mathrm{Cr}_{3} \mathrm{C}_{2}(\mathrm{NiCr})$ was most influenced to pitting type corrosion. Highest stable coating was $\mathrm{Cr}_{3} \mathrm{C}_{2}(\mathrm{NiCr})$.

Kaur et al. [6] examined the high temp. behavior of HVOF sprayed $\mathrm{Cr}_{3} \mathrm{C}_{2}(\mathrm{NiCr})$ coating. She concluded that no spallation was found during exposures. Therefore, coated T22 showed no cracks and spallation in both environment. Cross sectional analysis showed that penetration of oxygen was in margin, which was the sign of control of oxidation. Erosion-corrosion rate of steel was decreased by $35 \%$ after coating. In molten salt environment, $\mathrm{Cr}_{2} \mathrm{O}_{3}$ and $\mathrm{NiCr}_{2} \mathrm{O}_{4}$ acts as strong phases that resulted better result for high temperature corrosion resistance than in air environment.

Single et al. [7] determined characterization and corrosion resistance of plasma sprayed $\mathrm{HA}$ and $\mathrm{HA}-\mathrm{SiO}_{2}$ coatings on 
Ti6Al4V. He concluded that after $\mathrm{HA}+10 \% \mathrm{SiO}_{2}$ coating on Ti6Al4V corrosion resistance increased as compared to HA coating and bare specimen. After immersion in ringer's solution, No cracks were observed on both coated surfaces. Before and after corrosion testing in ringer's solution, both the coatings showed $\mathrm{HA}+10 \% \mathrm{SiO}_{2}$ coating converts into irregular shaped particles and $\mathrm{HA}$ coating hold its morphology. Therefore, $\mathrm{HA}+10 \% \mathrm{SiO}_{2}$ coating became more corrosion resistant and less porous.

Kumar et al. [8] investigated the cyclic oxidation behavior of bare and $\mathrm{Cr}_{3} \mathrm{C}_{2}-25$ ( $\mathrm{NiCr}$ ) coated super alloy at elevated temperature $\mathrm{He}$ observed that coated sample weight gain was one -fourth of weight gain of bare specimen and for 100 cycles coating at $900^{\circ} \mathrm{C}$ proved influenced. Parabolic rate constant $(\mathrm{kp})$ for coated superni600 was 28 times less than bare .XRD analysis showed the presence of $\mathrm{Cr}_{2} \mathrm{O}_{3}$, $\mathrm{Cr}_{23} \mathrm{C}_{6}, \mathrm{NiCr}_{2} \mathrm{O}_{4}$ and $\mathrm{Cr}_{7} \mathrm{C}_{3}$ in scale after oxidation which made coated superni600 oxidation resistant. Coating with D-gun technique provided protection to substrate from hot corrosion.

Singh et al.[9] done investigations of plasma-sprayed hydroxyapatite-calcium phosphate coatings on 316L SS, in vitro corrosion. He investigated that $\mathrm{HA}+20 \% \mathrm{CaP}$ was less crystalline than $\mathrm{HA}+10 \% \mathrm{CaP}$ and $\mathrm{HA}$ coatings. After $\mathrm{HA}$ coating, corrosion resistance increased than uncoated, $\mathrm{HA}+20 \% \mathrm{CaP}$ and $\mathrm{HA}+10 \% \mathrm{CaP}$. But no cracks were found on all the three coatings.

Mudgal et al. [10] investigated the hot corrosion behavior of some super alloys in a simulated incinerator in environment at $900^{\circ} \mathrm{C}$. She concluded that superni600 and superni718 showed less weight gain than superco605. In case of Nibased alloys, a thin scale was observed but in case of cobaltbased alloys, scale was thick. In superco605 $\mathrm{CoO}, \mathrm{NiWO}_{4}$, $\mathrm{NiCr}_{2} \mathrm{O}_{4}$ and $\mathrm{CoCr}_{2} \mathrm{O}_{4}$ were formed and $\mathrm{NiCr}_{2} \mathrm{O}_{4}$ and $\mathrm{Cr}_{2} \mathrm{O}_{3}$ in superni600 and superni718. $\mathrm{Ni}$ - based alloys suitable for incinerator environment while Co-based alloys unsuitable for incinerator environment.

Rana et al. [11] examined the stepwise depletion of coating element as a result of hot corrosion of NiCrAlY coatings. She concluded that due to formation of $\mathrm{Al}_{2} \mathrm{O}_{3}$ layer at coating interface, $\mathrm{NiCrAlY}$ coating were observed as corrosion resistant. $\mathrm{Al}_{3} \mathrm{Y}$ phase after 100 cycles, also increased the hot corrosion resistant and from 100 to 200 cycles, minimum corrosion was observed. Upto initial 5 cycles, $\mathrm{NiV}_{2} \mathrm{O}_{8}$ was formed. $\mathrm{YVO}_{4}$ also formed when $\mathrm{Y}$ reacts with vanadium and at interface, $\mathrm{Al}$ rich layer was observed.

Mudgal et al. [12] investigated the corrosion behavior of bare, $\mathrm{Cr}_{3} \mathrm{C}_{2}-25 \% \mathrm{NiCr}+0.4 \% \mathrm{CeO}_{2}$ coated superni600 under molten salt at $900^{\circ} \mathrm{C}$. She concluded that bare superni600 corroded in $\mathrm{Na}_{2} \mathrm{So}_{4}-25 \mathrm{Nacl}$ showed loss in weight due to some internal oxidation and had pores in scale, for 100 cycles at $900^{\circ} \mathrm{C}$. While coated specimens showed thick scale and weight gain. All the three cases had
$\mathrm{Cr}_{2} \mathrm{O}_{3}, \mathrm{NiCr}_{2} \mathrm{O}_{4}, \mathrm{Cr}_{23} \mathrm{C}_{6}, \mathrm{Na}_{2} \mathrm{CrD}_{4}$ in both corroded coatings and $\mathrm{CeO}_{2}, \mathrm{CeS}$ in $\mathrm{Cr}_{3} \mathrm{C}_{2}-25(\mathrm{NiCr})+0.4 \mathrm{CeO}_{2}$.

Rana et al. [13] done high temp. Oxidation and hot corrosion studies on NiCrAlY coatings deposited by flame spray technique. She concluded that NiCrAlY coatings successfully deposited by HVOF tech. On superni76 and superni76 coating provided high temp. Oxidation in both environments i.e. air and molten salt environment. Preoxidized region of coatings consisted alumina and unoxidized region consisted $\mathrm{Ni}$ and $\mathrm{Cr}$ which acts as air oxidation resistant. After 100 cycles of air oxidation, preoxidized region remained unaffected.

Shukla et al. [14] analysed the surface engineering analysis of $\mathrm{HVOF}$ sprayed $\mathrm{Cr}_{3} \mathrm{C}_{2}-\mathrm{NiCr}$ coating under high temp. Oxidation. $\mathrm{He}$ concluded that $\mathrm{Cr}_{3} \mathrm{C}_{2}-\mathrm{NiCr}$ coatings successfully deposited on $310 \mathrm{~S}$ by $\mathrm{HVOF}$ tech. Upto 500 hours and coating had dense structure. Coating's microhardness was lies between 775-1014Hv. Presence of $\mathrm{Cr}$ and $\mathrm{Ni}$ oxides showed by coating oxide scale which provided good corrosion and wear resistance.

Grewal et al. [15] checked the effect of sliding velocity on wear behaviour of TiAlN coatings. He concluded that in nanostructured coating, formation of titanium oxides and aluminium oxides provided protection against high oxidation, wear and good thermal stability while in conventional coating, oxides breakaway \& removed from the surface of the substrate. When sliding velocities were $0.5,1$ and $2 \mathrm{~m} / \mathrm{sec}$. with constant $10 \mathrm{~N}$ load, Nanostructured TiAlN coating at $200^{\circ} \mathrm{C}$ was best wear resistant than Nanostructured TiAlN coating at $500^{\circ} \mathrm{C}$, conventional TiAlN coating and bare AISI-304 boiler steel.

Rana et al. [16] studied the microstructural features and behavior of nano and conventional NiCrAlY coatings developed by LVOF process. She concluded that high interplay oxidation was the main cause of changes in oxidation mechanism of MC coatings and NC coatings .NC coatings hold the phases of the starting milled powder. The $\mathrm{NC} \mathrm{NiCrAlY} \mathrm{coatings} \mathrm{were} \mathrm{better} \mathrm{oxidation} \mathrm{resistant} \mathrm{than}$ MC coatings.

Mudgal et al. [17] investigated the hot corrosion behavior of bare , $\mathrm{Cr}_{3} \mathrm{C}_{2}-\mathrm{NiCr}$ and, $\mathrm{Cr}_{3} \mathrm{C}_{2}-(\mathrm{NiCr})+0.2$ wt. $\% \mathrm{Zr}$ coated superni718 at $900^{\circ} \mathrm{C}$. $\mathrm{Cr}_{3} \mathrm{C}_{2}-\mathrm{NiCr}$ coating provided great corrosion resistance to superni718 under $\left(\mathrm{Na}_{2} \mathrm{So}_{4}+\mathrm{K}_{2} \mathrm{So}_{4}+\right.$ $\mathrm{NaCl}+\mathrm{kCL})$ and $\mathrm{Na}_{2} \mathrm{So}_{4}+\mathrm{NaCl}$ salt environment. Zirconium addition in coating reduces the weight gain tendency. $\mathrm{Cr}_{2} \mathrm{O}_{3}$ and spinel of nickel and chromium protected the coating from corrosion.

\section{DISCUSSION}

Thermal sprayed coatings used against corrosion and corrosion wear. There were some reasons to use thick thermal sprayed coatings in industries. The reasons are as follows: 
1. It provided some beneficial properties to the substrate.

2. With low or no heat input, it could be applied to substrate.

3. Thermal sprayed coatings could be recoated the damaged or worn coatings without any changes in dimensions and properties.

4. Some of thermal processes could be used to spray big parts easily.

There were also some negative points of this coating like.

1. It was impossible to coat deep cavities and small parts by this coating process.

2. It had pores and cracks which resulted degradation.

Hence post- treatments like annealing, sealing, laser glazing etc. must to remove pores. These post-treatments increased the cost of coating [2]. Coating on 347 boiler steel by HVOF achieved great results and sprayed coating consisted irregular shaped splats which were interconnected. Corrosion loss for $347 \mathrm{H}$ steel in molten salt solution was high than corrosion loss in air and bare $347 \mathrm{H}$ steel in both environment suffered accelerated oxidation .Coated $347 \mathrm{H}$ steel showed better corrosion resistance in both environment than bare steel [3]. Kaur et al. [4] examined the surface engineering of D-gun sprayed $\mathrm{Cr}_{3} \mathrm{C}_{2}-\mathrm{NiCr}$ coating under high temp. Oxidation and Oxidation erosion environment. She concluded that coating on T22 boiler steel by D-gun achieved great results and coating had spongy structure. Higher weight loss occurred by bare specimen than coated at $700+10^{\circ} \mathrm{C} / 700-10^{\circ} \mathrm{C}$. Coated T22 steel resulting good oxidation erosion resistance than uncoated $\mathrm{T} 22$. $\mathrm{NiCr}$ coatings were high corrosion resistant or had low corrosion rate and pitting corrosion resistance . But by adding $\mathrm{Cr}_{3} \mathrm{C}_{2}$ in $\mathrm{NiCr}$, corrosion resistance had increased more. $\mathrm{NiCrAl}$ coating had highest pitting potential value $\mathrm{But} \mathrm{Cr}_{3} \mathrm{C}_{2}(\mathrm{NiCr})$ was most influenced to pitting type corrosion. Highest stable coating was $\mathrm{Cr}_{3} \mathrm{C}_{2}$ (NiCr)[5]. Kaur et al. [6] examined the high temperature behavior of $\mathrm{HVOF}$ sprayed $\mathrm{Cr}_{3} \mathrm{C}_{2}$ (NiCr) coating. She concluded that no spallation was found during exposures. Therefore, coated T22 showed no cracks and spallation in both environment. Cross sectional analysis showed that penetration of oxygen was in margin, which was the sign of control of oxidation.

Erosion-corrosion rate of steel was decreased by $35 \%$ after coating .In molten salt environment, $\mathrm{Cr}_{2} \mathrm{O}_{3}$ and $\mathrm{NiCr}_{2} \mathrm{O}_{4}$ acts as strong phases that resulted better result for high temp. corrosion resistance than in air environment. After $\mathrm{HA}+10 \% \mathrm{SiO}_{2}$ coating on $\mathrm{Ti} 6 \mathrm{Al} 4 \mathrm{~V}$ corrosion resistance increased as compared to HA coating and bare specimen. After immersion in ringer's solution, No cracks were observed on both coated surfaces. Before and after corrosion testing in ringer's solution, both the coatings showed $\mathrm{HA}+10 \% \mathrm{SiO}_{2}$ coating converts into irregular shaped particles and HA coating hold its morphology. Therefore, $\mathrm{HA}+10 \% \mathrm{SiO}_{2}$ coating became more corrosion resistant and less porous[7]. Kumar et al. [8] investigated the cyclic oxidation behavior of bare and $\mathrm{Cr}_{3} \mathrm{C}_{2}-25(\mathrm{NiCr})$ coated super alloy at elevated temperature $\mathrm{He}$ observed that coated sample weight gain was one -fourth of weight gain of bare specimen and for 100 cycles coating at $900^{\circ} \mathrm{C}$ proved influenced. Parabolic rate constant $(\mathrm{kp})$ for coated superni600 was 28 times less than bare .XRD analysis showed the presence of $\mathrm{Cr}_{2} \mathrm{O}_{3}, \mathrm{Cr}_{23} \mathrm{C}_{6}, \mathrm{NiCr}_{2} \mathrm{O}_{4}$ and $\mathrm{Cr}_{7} \mathrm{C}_{3}$ in scale after oxidation which made coated superni600 oxidation resistant. Coating with D-gun technique provided protection to substrate from hot corrosion. $\mathrm{HA}+20 \% \mathrm{CaP}$ was less crystalline than $\mathrm{HA}+10 \% \mathrm{CaP}$ and $\mathrm{HA}$ coatings. After HA coating, corrosion resistance increased than uncoated, $\mathrm{HA}+20 \% \mathrm{CaP}$ and $\mathrm{HA}+10 \% \mathrm{CaP}$. But no cracks were found on all the three coatings [9]. Superni600 and superni718 showed less weight gain than superco605. In case of Ni-based alloys, a thin scale was observed but in case of cobalt-based alloys, scale was thick. In superco605 $\mathrm{CoO}, \mathrm{NiWO}_{4}, \mathrm{NiCr}_{2} \mathrm{O}_{4}$ and $\mathrm{CoCr}_{2} \mathrm{O}_{4}$ were formed and $\mathrm{NiCr}_{2} \mathrm{O}_{4}$ and $\mathrm{Cr}_{2} \mathrm{O}_{3}$ in superni600 and superni718. Ni- based alloys suitable for incinerator environment while Co-based alloys unsuitable for incinerator environment [10]. Due to formation of $\mathrm{Al}_{2} \mathrm{O}_{3}$ layer at coating interface, NiCrAlY coating were observed as corrosion resistant. $\mathrm{Al}_{3} \mathrm{Y}$ phase after 100 cycles, also increased the hot corrosion resistant and from 100 to 200 cycles, minimum corrosion was observed. Upto initial 5 cycles, $\mathrm{NiV}_{2} \mathrm{O}_{8}$ was formed . $\mathrm{YVO}_{4}$ also formed when $\mathrm{Y}$ reacts with vanadium and at interface, Al rich layer was observed[11]. Bare superni600 corroded in $\mathrm{Na}_{2} \mathrm{So}_{4}-25 \mathrm{Nacl}$ showed loss in weight due to some internal oxidation and had pores in scale, for 100 cycles at $900^{\circ} \mathrm{C}$. While coated specimens showed thick scale and weight gain.

All the three cases had $\mathrm{Cr}_{2} \mathrm{O}_{3}, \mathrm{NiCr}_{2} \mathrm{O}_{4}, \mathrm{Cr}_{23} \mathrm{C}_{6}, \mathrm{Na}_{2} \mathrm{CrD}_{4}$ in both corroded coatings and $\mathrm{CeO}_{2}, \mathrm{CeS}$ in $\mathrm{Cr}_{3} \mathrm{C}_{2^{-}}$ $25(\mathrm{NiCr})+0.4 \mathrm{CeO}_{2}[12]$. NiCrAlY coatings successfully deposited by HVOF tech. On superni76 and superni76 coating provided high temp. Oxidation in both environments i.e. air and molten salt environment. Preoxidized region of coatings consisted alumina and unoxidized region consisted $\mathrm{Ni}$ and $\mathrm{Cr}$ which acts as air oxidation resistant. After 100 cycles of air oxidation, preoxidized region remained unaffected [13]. $\mathrm{Cr}_{3} \mathrm{C}_{2}-\mathrm{NiCr}$ coatings successfully deposited on $310 \mathrm{~S}$ by HVOF tech. Upto 500 hours and coating had dense structure. Coating's microhardness was lies between 775-1014Hv. Presence of $\mathrm{Cr}$ and $\mathrm{Ni}$ oxides showed by coating oxide scale which provided good corrosion and wear resistance [14].

In nanostructured coating, formation of titanium oxides and aluminium oxides provided protection against high oxidation, wear and good thermal stability while in conventional coating, oxides breakaway \& removed from the surface of the substrate. When sliding velocities were $0.5,1$ and $2 \mathrm{~m} / \mathrm{sec}$. with constant $10 \mathrm{~N}$ load, Nanostructured TiAlN coating at $200^{\circ} \mathrm{C}$ was best wear resistant than Nanostructured TiAlN coating at $500^{\circ} \mathrm{C}$, conventional TiAlN coating and bare AISI-304 boiler steel[15]. High interplay oxidation was the main cause of changes in oxidation mechanism of MC coatings and NC coatings .NC coatings hold the phases of the starting milled powder. The 
$\mathrm{NC} \mathrm{NiCrAlY} \mathrm{coatings} \mathrm{were} \mathrm{better} \mathrm{oxidation} \mathrm{resistant} \mathrm{than}$ MC coatings [16]. $\mathrm{Cr}_{3} \mathrm{C}_{2}-\mathrm{NiCr}$ coating provided great corrosion resistance to superni718 under $\left(\mathrm{Na}_{2} \mathrm{So}_{4}+\mathrm{K}_{2} \mathrm{So}_{4}+\mathrm{NaCl}+\mathrm{kCL}\right)$ and $\mathrm{Na}_{2} \mathrm{So}_{4}+\mathrm{NaCl}$ salt environment. Zirconium addition in coating reduces the weight gain tendency. $\mathrm{Cr}_{2} \mathrm{O}_{3}$ and spinel of nickel and chromium protected the coating from corrosion [17].

\section{CONCLUSION}

Thermal spraying techniques are mostly used coating technique to enhance surface performance.

1. Ni-based alloys perform better than Co-based alloys.

2. $\mathrm{Cr}_{3} \mathrm{C}_{2}-\mathrm{NiCr}$ show excellent results in the field of coatings.

3. Maximum corrosion attack occurs around $900^{\circ} \mathrm{C}$ temperature.

\section{REFERENCES}

[1] Chawla, Sidhu and Puriand Prakash, "Performance of plasma sprayed nanostructured and conventional coatings", Journal of the Australian Ceramic Society, Vol. 44, pp. 56-62, 2008.

[2] Fauchais and Vardelle, "Thermal sprayed coatings used against corrosion and corrosive wear", SPCTS, UMR 7315, France, 2012.

[3] Kaur, Singh and Prakash, "High temperature corrosion studies of HVOF sprayed $\mathrm{Cr}_{3} \mathrm{C}_{2}-\mathrm{NiCr}$ coating on $\mathrm{SAE}-347 \mathrm{H}$ boiler steel", Journal of Thermal Spray Technology, Vol. 18, No. 1, pp. 619-632, 2009.

[4] Kaur, Singh and Prakash, "Surface engineering analysis of D-gun sprayed $\mathrm{Cr}_{3} \mathrm{C}_{2}-\mathrm{NiCr}$ coating under high temperature oxidation and oxidation - erosion environments", Journal of Surface and Coating Technology, Vol. 206, pp. 530-541, 2011.

[5] Arrieta, Porcayo, Salinas, Chacon, Martinez and Gonzaloz, "Corrosion behavior of $\mathrm{Ni}-\mathrm{Cr}$ based coatings in simulated human body fluid environment", International Journal of Electro-chemical Science, Vol. 6, pp. 3644-3655, 2011.
[6] Kaur, Singh and Prakash, "High temperature behavior of HVOF sprayed $\mathrm{Cr}_{3} \mathrm{C}_{2}-\mathrm{NiCr}$ coating", Journal of Metallurgicaland Materials Transactions A, Vol. 43A, pp. 2979-2993, 2012.

[7] Singh, H.Singhand Sidhu, "Characterization and corrosion resistance of plasma sprayed $\mathrm{HA}$ and $\mathrm{HA}-\mathrm{SiO}_{2}$ coatings on Ti6Al4V", Journal of Surface and Coatings Technology, Vol. 228, pp. 242-247, 2013.

[8] Kumar, Mudgal, S.Singh and Prakash, "Cyclic oxidation behavior of bare and $\mathrm{Cr}_{3} \mathrm{C}_{2}-25(\mathrm{NiCr})$ coated super alloy at elevated temperature", Adv. Mat. Lett., Vol. 4, No. 10, pp. 754-761, 2013.

[9] Singh, H.Singh and Sidhu, "In vitro corrosion investigations of plasma-sprayed hydroxyapatite and hydroxyapatite - calcium phosphate coatings on 316LSS", Bull. Mater. Sci., Vol. 37, pp. 1519$1528,2014$.

[10] Mudgal, S.Singh and Prakash, "Hot corrosion behavior of some super alloys in a simulated incinerator environment at $900^{\circ} \mathrm{C}$ ", Journal of materials engineering and performance, Vol. 23, No. 1, pp. 238-249, 2014.

[11] Rana, Jayaganthan and Prakash, "Stepwise depletion of coating elements as a result of hot corrosion of NiCrAlY coatings", Journal of Materials Engineering and Performance, Vol. 23, No. 2, pp. 643650, 2014.

[12] Mudgal, Kumar, S.Singh and Prakash, "Corrosion behavior of bare $\mathrm{Cr}_{3} \mathrm{C}_{2}-25 \% \mathrm{NiCr}$ and $\mathrm{Cr}_{3} \mathrm{C}_{2}-25 \%(\mathrm{NiCr})+0.4 \% \mathrm{CeO}_{2}$ coated superni600 under molten salt at $900^{\circ} \mathrm{C}$ ", Journal of Materials Engineering and Performance, 2014.

[13] Rana, Mohapatra, Jayagathan and Prakash, "High temperature oxidation and hot corrosion studies on NiCrAlY coatings deposited by flame spray technique", Journal of Thermal Spray Technology, 2015.

[14] Shukla, Jayaganthan and Tewari, "Surface engineering analysis of $\mathrm{HVOF}$ sprayed $\mathrm{Cr}_{3} \mathrm{C}_{2}-$ NiCrcoating under high temperature oxidation", International Journal of Surface Engineering and Materials Technology, Vol. 4, pp. 44-49, 2014.

[15] Grewal, Sidhu and Prakash, "Effect of sliding velocity on wear behaviour of TiAlN coatings", Advanced Materials Research, Vol. 1137, pp. 24-38, 2016.

[16] Rana, Jayaganthan and Prakash, "Micro-structural features and oxidation behavior of nano and conventional NiCrAlY coatings developed by LVOf process", Journal of Surface and Coatings Technology, Vol. 260, pp. 28-33, 2014.

[17] Mudgal, S.Singh and Prakash, "Hot corrosion behavior of bare, $\mathrm{Cr}_{3} \mathrm{C}_{2}$ $-\mathrm{NiCr}$ and $\mathrm{Cr}_{3} \mathrm{C}_{2}-(\mathrm{NiCr})+0.2 \mathrm{wt} \% \mathrm{Zr}$ coated superni718 at $9000 \mathrm{C}$ ", Journal of Materials Engineering and Performance, 2014. 